\title{
Diagnostic Challenges and Extraordinary Treatment Response in Rare Malignant PEComa Tumor of the Kidney
}

\section{Zriedkavý malígny PECom obličky - diagnostická výzva a neobvyklá terapeutická odpoved'}

\author{
Hulova S. ${ }^{1,3}$, Sycova-Mila Z. ${ }^{1}$, Macak D. ${ }^{2}$, Janega P. ${ }^{4}$, Chovanec M. ${ }^{1}$, Mardiak J. ${ }^{1}$, Mego M. ${ }^{1}$ \\ $12^{\text {nd }}$ Department of Oncology, Faculty of Medicine, Comenius University, National Cancer Institute, Bratislava, Slovak Republic \\ 2Department of Pathology, National Cancer Institute, Bratislava, Slovak Republic \\ ${ }^{3} 1^{\text {st }}$ Department of Surgery, Pavol Jozef Šafárik University in Košice, Slovak Republic \\ ${ }^{4}$ Department of Pathology, Faculty of Medicine, Comenius University, National Cancer Institute, Bratislava, Slovak Republic
}

\begin{abstract}
Summary
Background: Epithelioid angiomyolipoma (EAML) of the kidney, in contrast to classic benign renal angiomyolipoma, is a rare mesenchymal neoplasm with malignant potential. Representing a member of the perivascular epithelioid cells (PEComa) tumor family arising from the perivascular epithelioid cells, its accurate diagnosis and therapeutic approach remains challenging. Methods: We report a case of a patient with malignant EAML, initially treated as renal cell carcinoma (RCC) at our institution. In this paper, we briefly summarize current status of clinical and histopathological knowledge of renal PEComas with metastatic potential and reconsider the diagnostic and therapeutic approach in this particular case to highlight the risk of misdiagnosis, malignant potential of renal PEComas and to demonstrate an unexpected treatment response. Results: The patient in our case was diagnosed with chromophobe RCC with sarcomatoid features. She underwent a radical nephrectomy and epinephrectomy with a satisfactory postoperative history. Local recurrence urged chemotherapy commencement with sunitinib in the first line, and shortly afterwards, the patient was enrolled in a clinical trial with everolimus, with an extraordinary favorable treatment response for 30 months. Following the extirpation of single abdominal nodularity after 36 months of treatment with mTOR inhibitor, and proceeding the everolimus administration, the disease slowly progressed to the right liver lobe, resulting in right hemihepatectomy in another 24 months. The immunoprofile of liver metastases with positive staining of melanoma markers and smooth muscle markers induced the revaluation of the primary tumor and abdominal nodularity specimen to an invasive EAML of the kidney. Further disease progression was unavoidable despite several chemotherapy regimens, and the patient died 104 months after primary diagnosis. Conclusions: Renal tumors with adverse radiographic and histopathological features should become candidates for immunohistochemical staining as its omission frequently leads to a misdiagnosis, as showed in our case report. Atypical treatment response might suggest a possibility of a diagnostic mistake and should lead to reevaluation of the diagnostic and treatment process in the particular patient.
\end{abstract}

Key words

renal PEComa - epithelioid angiomyolipoma - diagnosis - everolimus
The authors declare they have no potential conflicts of interest concerning drugs, products, or services used in the study.

Autoři deklaruji, že $v$ souvislosti s předmětem studie nemaji žádné komerční zájmy.

The Editorial Board declares that the manuscript met the ICMJE recommendation for biomedical papers.

Redakční rada potvrzuje, že rukopis práce splnil ICMJE kritéria pro publikace zasílané do biomedicínských časopisů.

$\Xi^{\circ}$

MUDr. Soňa Hul'ová

2nd Department of Oncology

Faculty of Medicine

Comenius University

National Cancer Institute

Klenová 1

83310 Bratislava

Slovak Republic

e-mail: sonahulova@gmail.com

Submitted/Obdržané: 12. 09. 2018

Accepted/Prijaté: 17. 10. 2018

doi: 10.14735/amko2018448 


\begin{abstract}
Súhrn
Východiska: Epiteloidný angiomyolipóm (EAML) obličky na rozdiel od benígneho renálneho angiomyolipómu predstavuje zriedkavý nádor mezenchymálneho pôvodu, ktorý disponuje malígnym potenciálom. Patrí do skupiny PEComov - tumorov vyvstávajúcich z perivaskulárnych epiteloidných buniek. Jeho diagnostika a terapeutický prístup zostávajú výzvou. Metódy: Autori prezentujú pacienta s malígnym EAML, ktorý bol iniciálne liečený ako renal cell karcinóm (RCC). Až neobvyklá terapeutická odpoved’ vyústila k prehodnoteniu primárnej diagnózy. V príspevku je stručne sumarizovaný súčasný stav klinických a histopatologických poznatkov o renálnych PEComoch s dôrazom na ich metastatický potenciál a riziko diagnostického pochybenia. Prípad: Pacient s pôvodnou diagnózou chromofóbneho RCC so sarkomatoidnými črtami podstúpil radikálnu nefrektómiu a epinefrektómiu. Lokálna rekurencia ochorenia podnietila zahájenie prvej línie liečby sunitinibom a následné zaradenie pacienta do klinického skúšania s mTOR inhibítorom s neobvykle priaznivou odpoved’ou v trvaní 30 mesiacov. Pomalá progresia ochorenia si vyžiadala extirpáciu solitárneho abdominálneho ložiska 36 mesiacov po zahájení liečby everolimom a napokon i pravostrannú hemihepatektómiu o d'alších 24 mesiacov. Imunoprofil pečeňových metastáz s pozitivitou melanómových a hladkosvalových markerov vyústil v rekvalifikáciu primárneho nálezu a metastatických ložísk na invazívny EAML obličky. Ďalšia progresia ochorenia bola napriek viacerým líniám systémovej liečby neodvratná a pacient 104 mesiacov po úvodnom stanovení diagnózy chorobe podlahol. Záver: Berúc do úvahy zriedkavost' a malígny potenciál PEComov obličiek, renálne nádory s nepriaznivými radiografickými a histopatologickými črtami sa stávajú kandidátom na imunohistochemické vyšetrenie. Neobvyklá odpoved' na liečbu upozorňuje na riziko diagnostického omylu a mala by viest' k prehodnoteniu diagnosticko-liečebného procesu u konkrétneho pacienta.
\end{abstract}

Kl'účové slová

PECom obličky - epitelioidný angiomyolipóm - diagnostika - everolimus

\section{Introduction}

Epithelioid angiomyolipoma (EAML) of the kidney is a rarely diagnosed mesenchymal neoplasm with malignant potential, and it occurs sporadically or in association with tuberous sclerosis complex syndrome [1]. Renal angiomyolipomas (RAML) are considered a part of perivascular epithelioid cells (PEComa) tumor family, originating from perivascular epithelioid cells (which have no recognized non-malignant counterpart) [2]. These infrequent tumours are diagnosed predominantly in females and arise from gastrointestinal, urinary tract, retroperitoneum, female reproductive organs, abdomino-pelvic sites and skin. RAML and pulmonary lymphangioleiomyomatosis represent 2 major findings within the PEComa group [3].

Diagnosis of the epithelioid RAML remains challenging based upon its radiographic appearance and clinical presentation. Renal EAML may easily be misdiagnosed as renal cell carcinoma (RCC), renal sarcoma or medullary carcinoma. There is a strong evidence, supporting the key role of immunohistochemical evaluation in accurate diagnosis PEComas typically stain for melanocyte (HMB45, Melan-A, MITF) and muscle cells markers (smooth muscle actin, myosin, calponin) and are negative for cytokeratins $[4,5,6]$. While most of the angiomyolipoma PEComas have benign nature, according to the literature, approximately $30 \%$ of all cases potentially develop into invasive renal EAMLs, characterized by aggressive growth and high risk of metastatic spread, resulting in poor prognosis. Current treatment approach for invasive EAML includes radical surgical procedure and mTOR signaling pathway targeted systemic therapy; however, optimal treatment strategy has not been established yet [7]. Herein, we present a case of patient with EAML of the kidney, initially diagnosed as RCC until dissemination, and treated with everolimus with unexpected positive response.
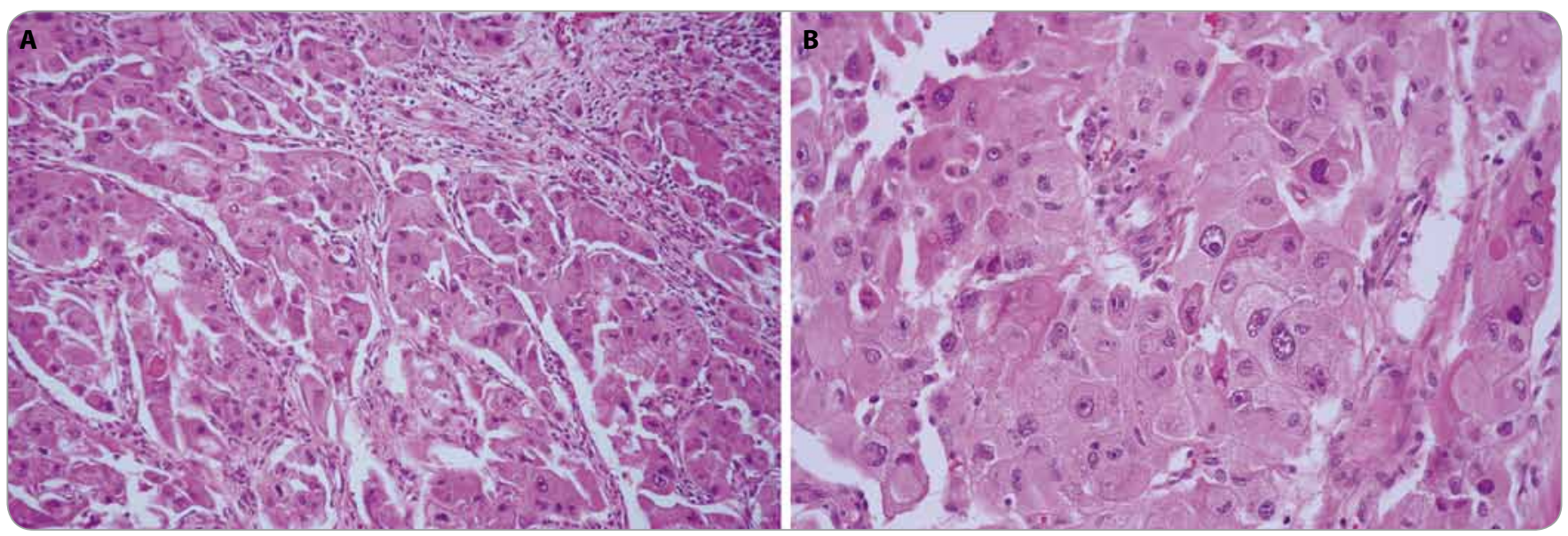

Fig. 1. Epithelioid angiomyolipoma of the kidney.

The histological image was characterized by epithelioid morphology of tumor cells, with enlarged atypical nuclei and prominent nucleoli. $H E, 200 \times(A), 400 \times(B)$. 

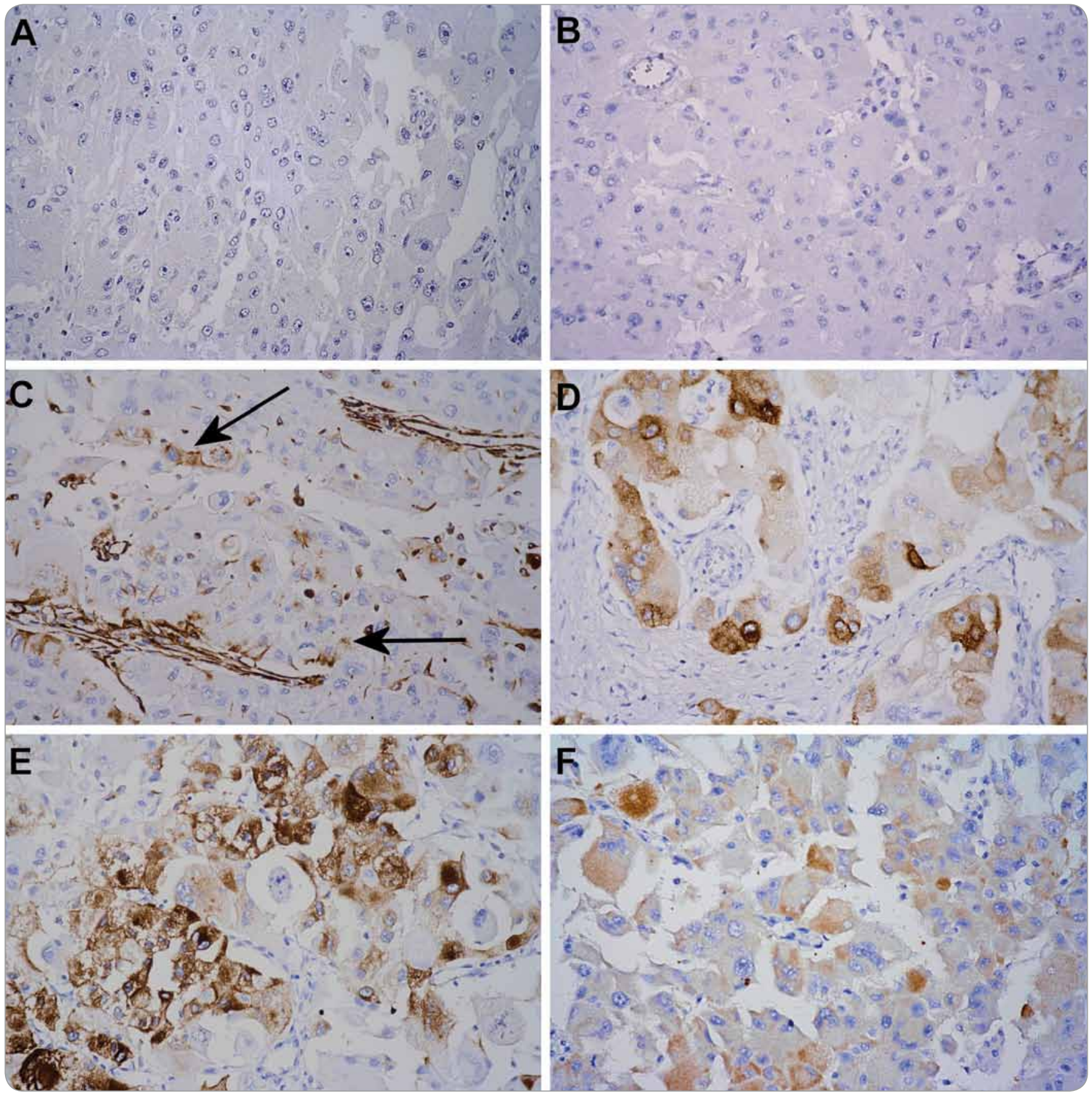

Fig. 2. Immunohistochemical profile of the tumor.

Tumor cells were negative for cytokeratins AE1/3 (A) and CD10 (B), focally positive for vimentin (C), and showed typical cytoplasmic positivity for Melan A (D) and HMB45 (E). The cells showed also cytoplasmic MyoD1 (F) positivity reported in these tumors [15]. IHC-Px-DAB, 400X.

\section{Clinical case details}

We present a case of 28-year-old Caucasian female with recently diagnosed ulcerative colitis. The suspicion for an expansive process of the right abdomen was expressed by the gastroenterologist as an external oppression of ascending colon and D3 (horizontal portion) duodenum was observed during the endoscopic examinations. CT and MRI scans revealed a multilocular capsulated tumor mass $11 \times 15 \times 14 \mathrm{~cm}$ (anteriorposterior dimension - AP $\times$ laterolateral dimension - LL $\times$ craniocaudal dimension - (C), encircling the right kidney, richly vascularized, with necrotic parts and intratumoral hemorrhages. The tumor was in close contact with segment
6 of the liver, with no signs of infiltration, no lymph nodes or distant sites were affected. The patient underwent a right radical nephrectomy and epinephrectomy, and the pathological examination revealed chromophobe RCC with sarcomatous features, nuclear grade 4 . Following surgery, the patient had been closely monitored and disease-free for 
15 months. Based on a CT-evidenced intra-abdominal recurrence, initial 6-month-period of treatment with sunitinib $(50 \mathrm{mg} /$ day, 4 weeks on, 2 weeks off) had been commenced. Because of an early disease progression, she was enrolled into a clinical trial with everolimus for advanced RCC. The disease was stable for 36 months. Subsequently, she required a surgical extirpation of a single progressing omental metastasis. She continued everolimus therapy for another 24 months, when the disease gradually spread to the right liver lobe, segment 6 and 7, and resulted in right hemihepatectomy. The tissue was microscopically evaluated as malignant melanoma, and the cells were immunohistochemically characterized CD10-, CK20-, RCC-, Hepatocyte-, TTF1-, $\mathrm{S} 100+$, Vimentin+, HMB45+, Melan $A+$, Ki67 30\%. Regarding the unusual clinical behavior, treatment response to mTOR inhibitor and inconsistent histopathologic results, biopsies from primary tumor, abdominal nodule and liver metastases were redefined to metastasizing epithelioid RAML (Fig. 1, 2). The patient proceeded in treatment with everolimus for another 3 months; however, she experienced a severe disease dissemination to the lungs with pleural effusion as well as to the liver and intraabdominally. Subsequently, several lines of systemic therapy (5-flurouracil/calcium leucovorine, gemcitabine, paclitaxel + carboplatin, vinorelbine) were administered without treatment response and the patient died 104 months after diagnosis.

\section{Discussion}

Perivascular epithelioid cell line was firstly described by Apitz in 1943, and it was designated as an abnormal myoblast in RAML [8]. In 2010, the World Health Organization introduced the definition of the PEComas as mesenchymal tumors composed of histologically and immunohistochemically distinctive perivascular epithelioid cells [9].

Two major findings of the PEComa family are RAML and pulmonary lymphangioleiomyomatosis. The first mentioned represents a rare soft tissue tumor and may demonstrate malignant poten- tial. It occurs sporadically $(50-70 \%$ of all cases) or it is associated with genetic alterations of tuberous sclerosis complex, an autosomal dominant congenital disease caused by the loss of heterozygosity in the $T S C 1$ region (9q34) or TSC2 region (16p) $[1,10,11]$. It has been recognized that tuberous sclerosis complex genes are involved in mTOR signaling pathway [10]. During the last 2 decades, more than 160 cases of angiomyolipoma PEComas have been published worldwide [6], identifying 3 major challenges of their management: diagnostic accuracy, necessity of risk stratification and determination of treatment strategies. Diagnostic process of EAML PEComa remains challenging. Given the histological evaluation, it may easily be confounded with RCC, renal sarcoma or melanoma $[2,4]$. The crucial role of immunohistochemistry in the differential diagnosis of renal EAML has been proven by numerous sources, including our clinical case, and should be considered especially in the presence of adversefeatures. Based on evidenced data, malignant PEComas should be considered in the differential diagnosis of large, well-circumscribed renal tumors with intratumoral hemorrhages and necrotic areas, predominantly if coagulative tumor necrosis, nuclear atypia and atypical mitosis are seen histologically $[12,13]$. The positivity of smooth muscle markers and melanoma markers are typical in most of renal PEComas. Moreover, current relevant data illustrate the need of EAMLs malignant potential assessment. EAMLs are extremely rare and account for approximately $5 \%$ of surgically removed angiomyolipomas [7]. The metastatic spread is observed among $20-30 \%$ of patients, and most frequently affected sites are liver, lungs and peritoneum $[11,14]$. The criteria for malignant potential of EAML have not been established yet. Therapeutic approach includes radical surgical procedure; regarding systemic treatment, mTOR inhibitors administration has shown promising results. Despite of primarily inaccurate diagnosis, the patient in this report benefited from mTOR inhibitor treatment and exhibited an extraordinary favorable response.

\section{Conclusion}

The tumors belonging to the PEComa family are not seen frequently, and their diagnostic and therapeutic management could be challenging. By reporting our clinical case, we point at increasing awareness about the possibility of PEComa occurrence and misdiagnosis, and emphasize the role of immunohistochemical examination in EAML. Secondly and equally important, we encourage the specialists to keep close attention to the clinical course of the disease, and in case of extraordinary treatment response, reconsider the primary finding and approach. Clinical evidence regarding renal EAML is emerging. Nevertheless, further investigation is needed to proceed in optimization of the medical care standards for patients with rare PEComas of the kidney.

\section{References}

1. Kuroda N, Pan CC. Renal angiomyolipomas: clinical and histological spectrum. Urol Sci $2011 ; 22(1): 40-42$.

2. Esheba Gel S, Esheba Nel S. Angiomyolipoma of the kidney: clinicopathological and immunohistochemical study. J Egypt Natl Canc Inst 2013; 25(3): 125-134. doi: 10.1016/j. jnci.2013.05.002

3. Hwang HC, Hwang, Jl, Hung SW et al. Epithelioid angiomyolipoma: an overview of five cases with the concept of PEComa. Chin J Radiol 2008; 33: 253-260.

4. Grant C, Lacy JM, Strup SE. A 22-year-old female with invasive epithelioid angiomyolipoma and tumor thrombus into the inferior vena cava: case report and literature review. Case Rep Urol 2013; 2013: 730369. doi: 10.1155/2013/730369.

5. Cao QH, Liu F, Xiao P et al. Coexistence of renal epithelioid angiomyolipoma and clear cell carcinoma in patients without tuberous sclerosis. Int J Surg Pathol 2015; 20(2): 196-200. doi: 10.1177/1066896911413576.

6. Singer E, Yau S, Johnson M. Retroperitoneal PEComa: case report and review of literature. Urol Case Rep 2018; 19: 9-10. doi: 10.1016/j.eucr.2018.03.012

7. He W, Cheville JC, Sadow PM et al. Epithelioid angiomyolipoma of the kidney: pathological features and clinical outcome in a series of consecutively resected tumours. Mod Pathol 2013; 26(10): 1355-1364. doi: 10.1038/modpathol.2013.72.

8. Apitz K. Die geschwulste und Gewebsmissbildungen Nierenrinde. II Midteilung Die mesenchymalen Neubildungen. Virchows Arch 1943; 31: 306-327.

9. Wildgruber $M$, Becker $K$, Feith $M$ et al. Perivascular epitheloid cell tumor (PEComa) mimicking retroperitonea liposarcoma. World J Surg Oncol 2014; 12: 3. doi: 10.1186/1477-7819-12-3.

10. Pan CC, Chung MY, Ng KF et al. Constant allelic alteration on chromosome 16p (TSC2 gene) in perivascular epithelioid cell tumour (PEComa): genetic evidence for the relationship of PEComa with angiomyolipoma. J Pathol 2008; 214(3): 387-393. 10.1002/path. 2289.

11. Jayaprakash PG, Mathews S, Azariah MB et al. Pure epithelioid perivascular cell tumour (epithelioid angiomyolipoma) of kidney: case report and literature review. 
J Cancer Res Ther 2014; 10(2): 404-406. doi: 10.4103/09731482.136672.

12. Kenerson H, Folpe AL, Takayama TK et al. Activation of the mTOR pathway in sporadic angiomyolipomas and other perivascular epithelioid cell neoplasms. Hum Pathol 2007; 38(9): 1361-1371. doi: 10.1016/j.humpath.2007.01.028.
13. Tirumani SH, Shinagare AB, Hargreaves J et al. Imaging features of primary and metastatic malignant epithelioid cell tumors. AJR Am J Roentgenol 2014; 202(2): 252-258. doi: 10.2214/AJR.13.10909

14. Chuang CK, Lin HC, Tasi HY et al. Clinical presentations and molecular studies of invasive renal epithelioid angio- myolipoma. Int Urol Nephrol 2017; 49(9): 1527-1536. doi: 10.1007/s11255-017-1629-4

15. Panizo-Santos A, Sola I, de Alava E et al. Angiomyolipoma and PEComa are immunoreactive for MyoD1 in cell cytoplasmic staining pattern. Appl Immunohistochem Mol Morphol 2003; 11(2): 156-160.

THE JOURNAL OF THE CZECH AND SLOVAK ONCOLOGICAL SOCIETIES

\section{KLINICKÁ ONKOLOGIE}

\section{Výzva k zasílání publikací}

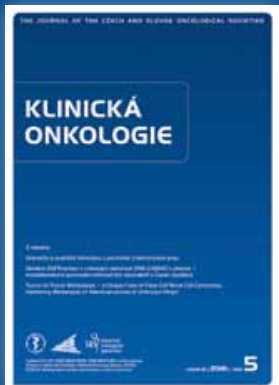

Přijímáme originální a přehledové práce, kazuistiky, stručná sdělení a další.

\section{Proč publikovat u nás?}

Vaše práce budou dohledatelné ve 4 světových bibliografických databázích včetně MEDLINE/PubMed.

Vaše práce budou čteny! Tištěná Klinická onkologie patří k nejčtenějším časopisům mezi klinickými onkology a radioterapeuty. Její internetové stránky byly v období roce 2017 navštíveny více než než 50 000× a proběhlo 8300 stažení clánku v pdf formátu.

Vaše práce budou uznávány při hodnocení grantů, pro obhajoby doktorského studia a pro habilitační a profesorské řízení.

\section{Podrobnosti na шயய.linkos.cz nєbo шயய.klinickaonkologie.cz,} e-mail: klinickaonkologie@mou.cz 